\section{Absolute monocyte count as a prognostic parameter in diffuse large $B$ cell lymphoma}

\author{
VICTORIA IRIGOÍN ${ }^{1}$, CAROLINA OLIVER ${ }^{1}$, STEFANÍA LÓPEZ ${ }^{2}$, \\ ANA INÉS LANDONI ${ }^{2}$, RAÚL GABÚS ${ }^{2}$, LILIÁN DÍAZ ${ }^{1}$
}

\begin{abstract}
Background: Prognosis of patients with Diffuse Large B Cell Lymphoma (DLBCL) is highly variable, and despite the use of modern immunochemotherapy regimens, almost $50 \%$ of patients will eventually relapse. Standard risk models, like the International Prognostic Index or the Revised International Prognostic Index (R_IPI) incorporate patient and tumor characteristics but do not consider variables related to host adaptive immunity which have been shown to be of significant prognostic value in non-Hodgkin lymphomas. Aim: To analyze the prognostic significance of the absolute monocyte count at diagnosis in diffuse large- $B$-cell lymphoma in a retrospective setting. Material and Methods: We reviewed data of 171 patients with DLBCL treated with Rituximab-based immunochemotherapy at two reference public Hospitals in Montevideo-Uruguay. The outcome measures were overall and relapse free survival. Results: The absolute monocyte count, analyzed as a dichotomized variable predicted progression-free and overall survival in low risk patients according to the R-IPI score. Worse outcomes were observed in those with high monocyte count al diagnosis. Conclusions: Absolute monocyte count could help in the identification of high-risk patients otherwise expected to have a good prognosis according to traditional scores.
\end{abstract}

(Rev Med Chile 2019; 147: 1553-1560)

Key words: Lymphoma, Large B-Cell, Diffuse; Monocytes; Prognosis.

\section{Recuento absoluto de monocitos como parámetro pronóstico en linfoma difuso de células B grandes}

Antecedentes: El pronóstico de pacientes con Linfoma Difuso de Células B Grandes (DLBCL) es muy variable y el $50 \%$ de los pacientes recae a pesar de uso de regímenes actualizados de inmuno-quimioterapia. Los modelos pronósticos clásicos como el International Prognostic Index o el Revised International Prognostic Index (R_IPI) incorporan características del paciente o del tumor pero no incorporan variables asociadas a la inmunidad adaptativa que tienen valor en linfomas no Hodgkin. Objetivo: Analizar retrospectivamente el valor pronóstico del recuento absoluto de monocitos al momento del diagnóstico en pacientes con DLBCL. Material y Métodos: Se revisó información de 171 pacientes con DLBCL tratados con inmuno-quimioterapia basada en rituximab
${ }^{1}$ Cátedra de Hematología.

Hospital de Clínicas. Montevideo,

Uruguay.

${ }^{2}$ Servicio de Hematología y

Trasplante de Médula Osea.

Hospital Maciel. Montevideo,

Uruguay.

This study received no financial support.

Recibido el 18 de julio de 2019 aceptado el 21 de noviembre de 2019.

Correspondencia a: Victoria Irigoín vicirigoin19@gmail.com 
en dos centros de referencia públicos de Montevideo, Uruguay. Las variables de resultado fueron la sobrevida global y libre de recaída. Resultados: El recuento absoluto de monocitos, tratado como una variable dicotómica, predijo la sobrevida libre de recaída en pacientes de bajo riesgo, de acuerdo al puntaje R-IPI. El pronóstico fue peor en pacientes con altos recuentos al momento del diagnóstico. Conclusiones: El recuento absoluto de monocitos puede identificar pacientes de alto riesgo, clasificados como de bajo riesgo por los puntajes tradicionales.

Palabras clave: Linfoma de Células B Grandes Difuso; Monocitos; Pronóstico.

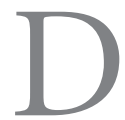
iffuse Large B-Cell Lymphoma (DLBCL) is an aggressive lymphoproliferative disorder that accounts for the majority (30-40\%) of non-Hodgkin's lymphomas (NHL) in the adult population. This entity has variable clinical, histological, immunophenotypic and cytogenetic features that translate into variable outcomes $^{1,2}$. The International Prognostic Index (IPI), developed in the pre-rituximab era, stratifies patients into 4 risk groups considering patient's and tumor's characteristics, and has been the main clinical tool used to predict outcome for patients with aggressive $\mathrm{NHL}^{3}$. The addition of the anti-CD20 monoclonal antibody rituximab to the standard chemotherapy led to a significant improvement in clinical outcomes ${ }^{4-6}$. A new prognostic score, the Revised-IPI (R-IPI) for patients treated with rituximab was developed in 2007 using the same variables considered in the IPI; it identifies 3 distinct prognostic groups with significantly different outcomes and provides a more clinically useful prediction of risk $^{7}$. With the use of immunochemotherapy, complete remission (CR) rates as high as $80 \%$ can be achieved ${ }^{4,5}$. However, there is still a group of high risk patients who have a 5 -year overall survival (OS) probability of less than $50 \%$. This heterogeneity in outcomes cannot be fully explained by the risk assigned by traditional prognostic scores, as even patients belonging to the same risk group often behave differently. Therefore, the identification of prognostic biomarkers able to better stratify the risk of these patients has become the focus of extensive research in the last years as it may allow for alternative treatment strategies to be considered in order to overcome high risk disease.

Gene expression profiling, immunohistochemistry-based determination of the cell of origin, cytogenetic aberrations and early interim analysis with positron emission tomography (PET/CT) during immunochemotherapy are all proposed methods that may identify high risk patients ${ }^{2,8-13}$. However, these techniques are expensive and many of them are not widely available, hence identifying cheaper and accessible biomarkers seems a valuable goal.

It has been demonstrated that monocytes, myeloid-derived cells (MDC) and other nurse like cells present in the tumor microenvironment are required to sustain the growth and survival of malignant B-cells in chronic lymphocytic leukemia ${ }^{14,15}$ and in T-cell lymphoproliferative disorders ${ }^{16}$. Circulating monocytes are a subtype of this highly diverse population. Chemokines and other tumor-associated factors may promote the migration of these cells to the tumor ${ }^{17}$ and alternatively, these cells may be generated de novo within the tumor microenvironment.

Some studies have shown that features related to host adaptive immunity and to the tumor microenvironment are significant prognostic variables in non-Hodgkin's lymphomas ${ }^{18,19}$.

The aim of this study was to analyze whether the absolute monocyte count (AMC) at diagnosis as part of the host adaptive immunity, could be an additional prognostic variable for patients with DLBCL treated with chemoimmunotherapy.

\section{Materials and Methods}

This study is a retrospective analysis of an unselected population of 171 patients with DLBCL treated in 2 public reference centers in Montevideo, Uruguay (Hospital de Clínicas and Hospital Maciel) between 2002 and 2017. Patients were included for analysis if they had a biopsy-proven newly diagnosed DLBCL and were treated with at least one cycle of rituximab- based chemoimmunotherapy with curative intention. Patients 
with primary nervous system lymphoma were excluded. Chemoimmunotherapy (R-CHOP, $\mathrm{R}-\mathrm{CEOP}, \mathrm{DaEPOCH}-\mathrm{R}$ ) was administered using standard doses and intervals. AMC was obtained from routine automated complete blood count (CBC) determination at the time of diagnosis prior to treatment administration. The cut off value considered for AMC was the normal one for both Hospital's laboratories $\left(700 / \mathrm{mm}^{3}\right.$ and $1000 \mathrm{~mm} /{ }^{3}$, respectively). Treatment response was defined according to the 2014 Lugano criteria ${ }^{20}$. All clinical and follow-up information was obtained from hospitals' clinical records. This study was approved by the Hospital de Clínicas' Ethics Committee and was conducted according to the Helsinki Declaration (2013).

\section{Study objectives}

The primary objective of the study was to determine the prognostic impact of the absolute monocyte count at diagnosis on OS and Relapse Free Survival (RFS). The secondary study objective was to determine whether the AMC could add in the prognostic power of the R-IPI score.

\section{Statistical analysis}

Non-parametric test as Chi square was used to compare qualitative variables, and T-test to compare quantitative continuous variables. RFS was calculated from the date of diagnosis to documented disease relapse or refractoriness to first line treatment. OS was calculated from the date of diagnosis until death. RFS and OS were assessed using the Kaplan-Meier method and comparison between risk groups was performed using the log rank test. Observations were censored on the date of the last follow-up or death. The value for statistical significance was 0,05 . A statistically significant value for AMC could not be determined by means of ROC analysis so the upper limit of normal value for the laboratories was considered for the AMC cut off value.

\section{Results}

\section{Patient characteristics}

Among the entire population, 171 patients received rituximab-based immunochemotherapy (R-CHOP or R-CHOP like) with a median of rituximab cycles of $6^{1-6}$. As summarized in Table 1, median age was 61 years (range 17-85) and 96 patients $(56,1 \%)$ were female. According to Ann Arbor Classification for disease stage, 71 patients $(41,5 \%)$ had stage I-II, $100(58,5 \%)$ had stage III-IV. Risk was stratified according to R-IPI score; 10 patients $(5,8 \%)$ had very good prognosis, 93 patients $(54,4 \%)$ had good prognosis and 68 patients $(39,8 \%)$ had adverse prognosis. Seven patients $(4,1 \%)$ were HIV positive. Median AMC at diagnosis was $620 / \mathrm{mm}^{3}$ (range $40-3,720$ ). At diagnosis, 57 patients $(33,3 \%)$ had high AMC and $114(66,7 \%)$ had low AMC according to the cut off value used for this study. Table 2 shows the population characteristics according to AMC at diagnosis

Table 1. Characteristics of the population

\begin{tabular}{|lc|}
\hline Patients characteristics $(\mathbf{n}=\mathbf{1 7 1})$ & $\mathbf{n}$ (\%) \\
$\begin{array}{l}\text { Age (years) } \\
\text { Median (range) }\end{array}$ & $61(17-85)$ \\
Gender & \\
$\quad$ Female & $96(56,1 \%)$ \\
Ann Arbor Stage & \\
I-II & $71(41,5 \%)$ \\
III-IV & $100(58,5 \%)$ \\
R-IPI & \\
Very low & $10(5,8 \%)$ \\
Low & $93(54,4 \%)$ \\
High risk & $68(39,8 \%)$ \\
Absolute monocyte count $\left(\mathrm{mm}^{3}\right)$ & \\
Median (range) & $620(40-3.720)$ \\
$\quad$ Low AMC & $114(66,7 \%)$ \\
High AMC & $57(33,3 \%)$ \\
\hline
\end{tabular}

AMC: absolute monocyte count.

Table 2. Characteristics of the population according to AMC

\begin{tabular}{|c|c|c|}
\hline $\begin{array}{l}\text { Patients characteristics } \\
(n=171)\end{array}$ & $\begin{array}{l}\text { Low AMC } \\
(n=114)\end{array}$ & $\begin{array}{c}\text { High AMC } \\
(n=57)\end{array}$ \\
\hline $\begin{array}{l}\text { Age (years) } \\
\text { Median (range) }\end{array}$ & $58(17-85)$ & \\
\hline $\begin{array}{l}\text { Gender } \\
\text { Female }\end{array}$ & $70(61,4 \%)$ & $26(45,6 \%)$ \\
\hline $\begin{array}{l}\text { Ann Arbor Stage } \\
\text { I-II } \\
\text { III-IV }\end{array}$ & $\begin{array}{l}50(44 \%) \\
64(56 \%)\end{array}$ & $\begin{array}{l}21(36,8 \%) \\
36(63 \%)\end{array}$ \\
\hline $\begin{array}{l}\text { R-IPI } \\
\text { Very low } \\
\text { Low } \\
\text { High risk }\end{array}$ & $\begin{array}{c}8(7 \%) \\
66(58 \%) \\
40(35 \%)\end{array}$ & $\begin{array}{l}2 \quad(3,5 \%) \\
27(47,4 \%) \\
28(49 \%)\end{array}$ \\
\hline
\end{tabular}

AMC: Absolute monocyte count. 


\section{Response to treatment}

At the end of treatment 116 patients $(67,8 \%)$ achieved CR, whereas $22(12,9 \%)$ achieved a partial response (PR), 2 (1,2\%) had stable disease and $18(10,5 \%)$ progressed. End of follow up was on December 2017. Remission was evaluated by means of PET/TC in 60 patients $(35 \%)$. Nine $(5,2 \%)$ patients were lost of follow-up before end of treatment evaluation and 4 patients were still on treatment (Table 3 ) at time of last follow-up. With a median follow-up of 28 months (0,6-149), $44(25,7 \%)$ patients relapsed. When response to treatment was analyzed according to AMC, 74,6\% of patients with low AMC achieved a CR vs $54,4 \%$ of those with high AMC ( $p=0,008)$.This population was comparable in terms of R-IPI score and there was no difference in the median cycles of rituximab among these groups $(p=0,159)$. When grouped according to R-IPI score, $90 \%$ of patients with very good prognosis achieved a CR, 69.9\% of those with good prognosis achieved a CR and $61,8 \%$ of poor prognosis achieved CR.

When response to treatment was evaluated considering AMC at diagnosis in the different R-IPI groups, $60(81,1 \%)$ patients in the very good and good R-IPI with low AMC at diagnosis achieved CR vs $14(48,3 \%)$ of those with high AMC $(\mathrm{p}=0,001)$. No difference was found in CR rates among patients with adverse R-IPI score according to $\mathrm{AMC}(60 \%$ vs $60,7 \% \mathrm{p}=0,953)$.

\section{Survival}

Estimated median OS at 4 years according to R-IPI score was $100 \%, 73 \%$ and $47 \%$ for very good, good and poor prognosis, respectively. (Figure 1). Median OS in the group of patients with high AMC was 44,9 months (range $12,8-76,9$ ) vs 131,6 months (range 88,8-174,4) for those with low AMC $(\mathrm{p}<0,0001)$ (Figure 2$)$. This population was comparable in terms of R-IPI score and

Table 3. Response to treatment

\begin{tabular}{|lr|}
\hline CR (Number/ \%) & $116 / 67,8 \%$ \\
\hline$P R$ & $22 / 12,9 \%$ \\
SD & $2 / 1,9 \%$ \\
PD & $18 / 10,5 \%$ \\
Lost of follow-up & $9 / 5,2 \%$ \\
\hline
\end{tabular}

median rituximab cycles. The median Relapse Free Survival (RFS) in the group of patients with R-IPI 0-2 was not reached in those with low AMC and was 12,8 months (range 3-22) in patients with high AMC $(\mathrm{p}=0,002)$ (Figure 3$)$. RFS in patients with poor R-IPI score was not statistically different when patients were analyzed according to AMC $(\mathrm{p}=0,901)$. In the subgroup of patients with very good and good R-IPI score the median OS

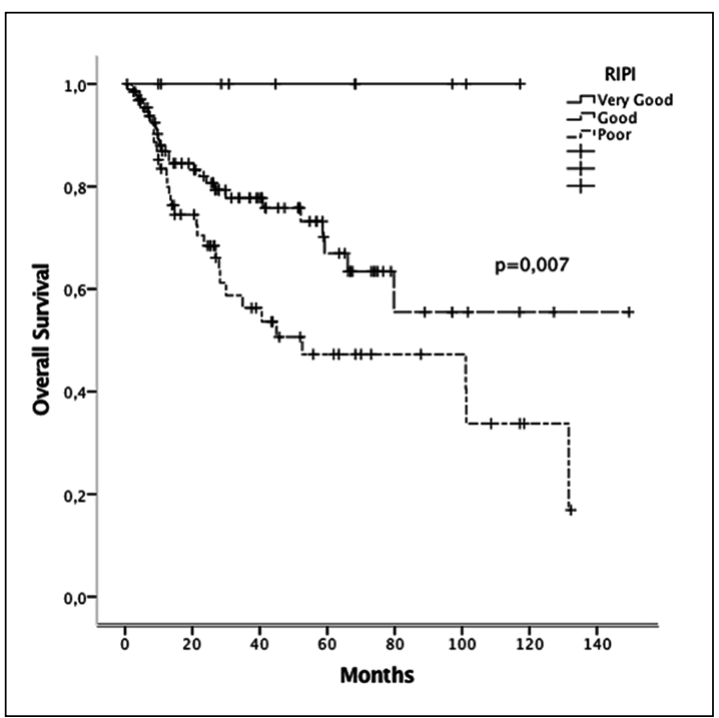

Figure 1. Overall Survival according to R-IPI score.

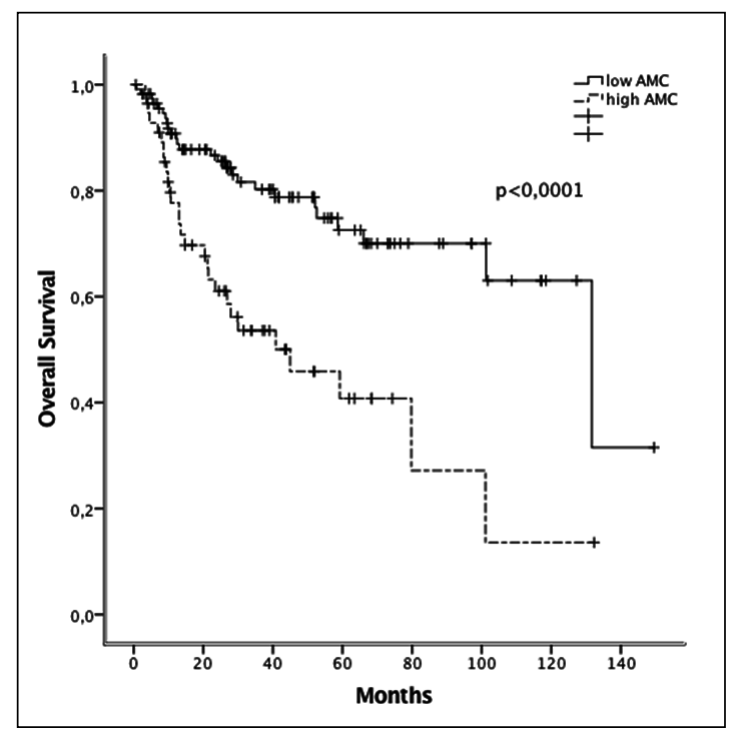

Figure 2. Overall Survival according to AMC. 


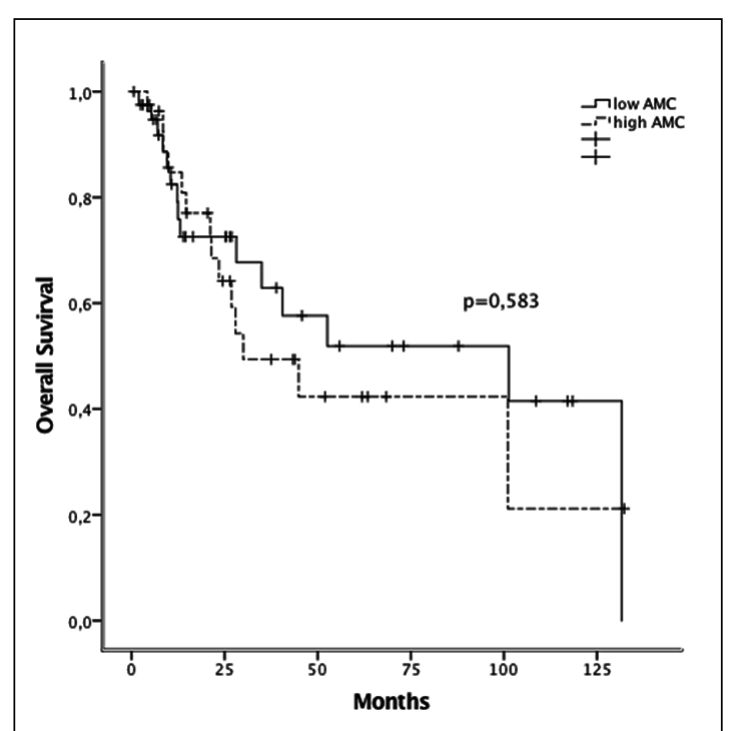

Figure 3. RFS in good and very good R-IPI score according to AMC.

in patients with low AMC had not been reached and it was 40,8 months in those with high AMC (range 0-83) p $<0,0001$ (Figure 4). There was no statistically significant difference in median OS in patients with poor risk according to AMC $(\mathrm{p}=0,58)$.

\section{Discussion}

Monocytes and myeloid derived cells have been demonstrated to have a host anti-tumor immunity suppression activity and that promote malignant lymphocyte's growth and survival by providing trophic stimulus. There is some evidence that elevated AMC is independently associated with inferior progression free survival (PFS) and OS in patients with DLBCL ${ }^{21-23}$. Tadmor et al. led a multi-center study that enrolled 1,017 patients showing that AMC $>630 \mathrm{~mm}^{3}$ at diagnosis was a predictor which identified a subset of high-risk patients in the rituximab era ${ }^{24}$. Porrata et al. suggested that peripheral Absolute Lymphocytes Count (ALC)/AMC ratio after each cycle of chemoimmunotherapy may predict prognosis and that ALC/AMC $<1.1$ was an independent parameter of OS and PFS in the R-CHOP era ${ }^{25}$. These studies have shown different means and timing of evaluation of the importance of monocytes in the

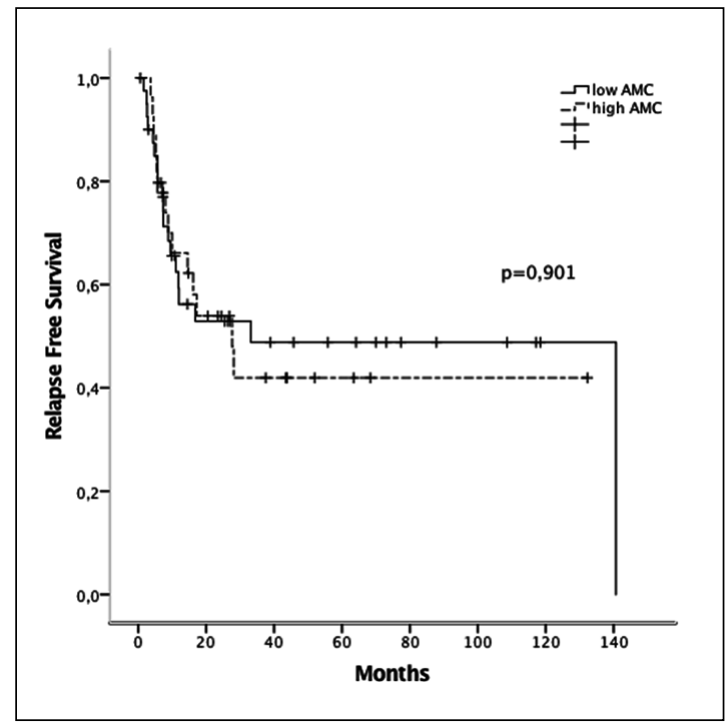

Figure 4. OS in very good and good RIPI according to AMC.

prognosis of patients with lymphoma. However, they have not analyzed this variable in the context of traditional prognostic scores. Taken all this evidence into account, incorporating features of host immunity and the tumor microenvironment into conventional prognostic models may provide additional valuable information.

In the present study we sought to investigate whether the AMC, as a biomarker for host immunity and the tumor microenvironment, affects survival in DLBCL, taking into consideration that this test is a widely available and cost accessible tool. In our cohort of patients with DLBCL, high absolute monocyte count at diagnosis was associated with an inferior CR rate, shorter RFS and OS in the group with very good and good prognosis according to R-IPI score. Elevated AMC at diagnosis was able to identify a subset of patients who despite having a very good or good prognosis according to R-IPI score had a RFS and OS rate comparable to those of the high-risk R-IPI group (Figure 5). Absolute monocyte count was thus able to provide additional prognostic information when used in conjunction with R-IPI score. This was particularly true for very good and good R-IPI cases.

Although this study has some limitations, such as being a retrospective study and has a limited number of patients, it illustrates an important ob- 


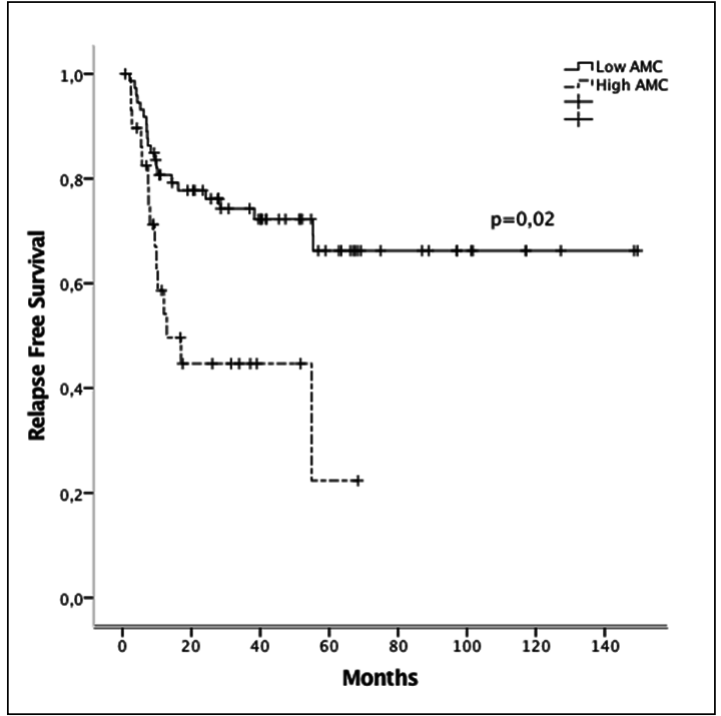

Figure 5. PFS in good and very good R-IPI score according to $A M C$.

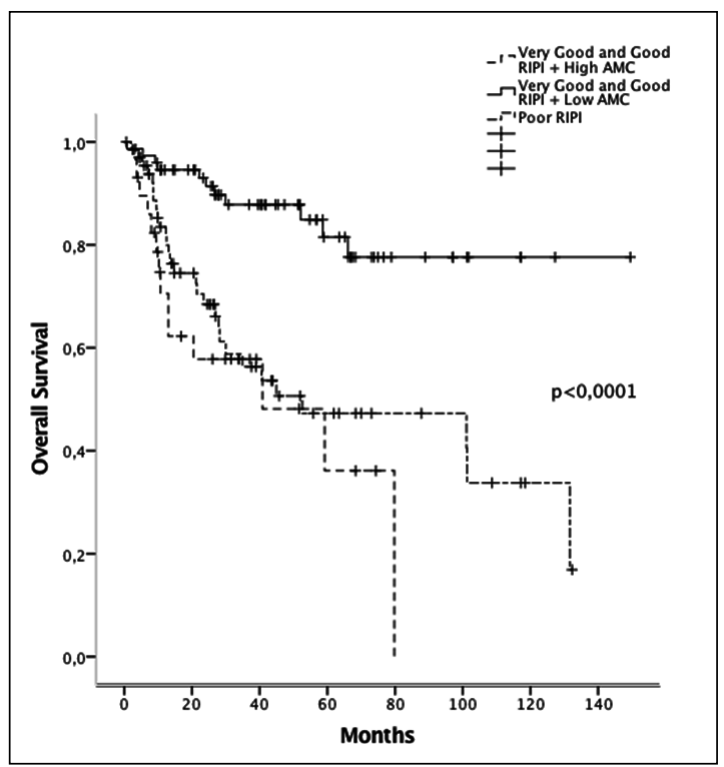

Figure 7. OS according to R-IPI and AMC value.

servation that can be of great value in this group of good prognostic risk DLBCL patients. Therefore, given the limited number of patients included in this retrospective study, the $\mathrm{AMC}$ prognostic value will require prospective validation in an independent and wider cohort of patients.

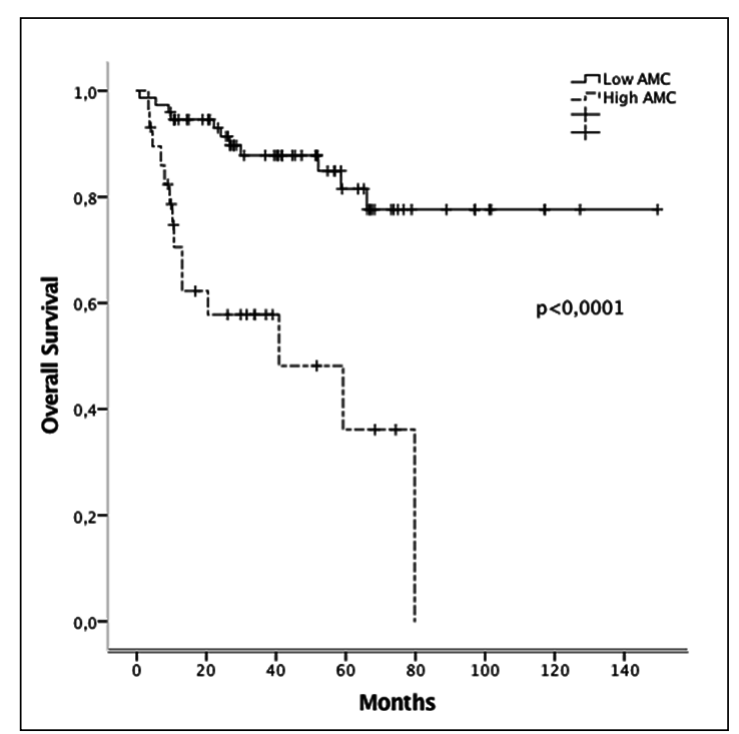

Figure 6. OS in very good and good RIPI according to AMC.

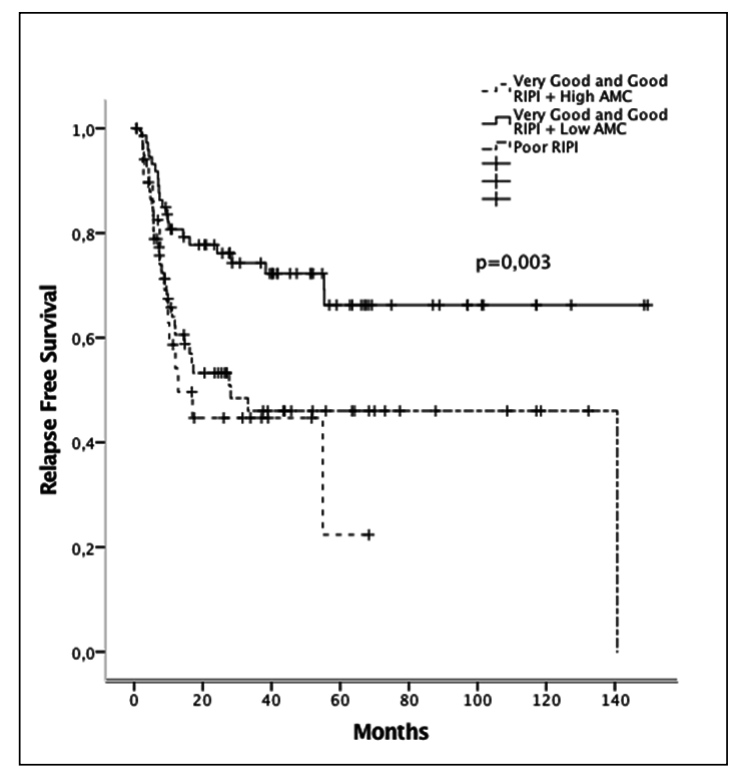

Figure 8. RFS according to R-IPI and AMC value.

\section{Conclusions}

This retrospective study shows that features related to host adaptive immunity may provide additional prognostic information to that included in traditional scores; in line to international 
publications that have suggested the importance of this compartment on lymphoproliferative neoplasms aggressiveness. Circulating monocytes, as part of this immune system have been proposed as potential markers, and a high circulating AMC has been shown to correlate with worse outcomes. This determination has the advantage of being widely available at no additional cost. In the future it would be interesting to correlate these findings with other biological features of the lymphoma itself, as the amount of tumor infiltrating macrophages or nurse like cells (derived from MDC).

\section{References}

1. Coiffier B. State-of-the-Art Therapeutics: Diffuse Large B-Cell Lymphoma. J Clin Oncol 2015; 23 (26): 6387-93.

2. Lossos IS. Molecular pathogenesis of diffuse large B-cell lymphoma. J Clin Oncol 2005; 23 (26): 6351-57.

3. Intenational Non-Hodgkin's Lymphoma Pronostic Factors Project. A Predictive Model for Aggressive Non-Hodgkin's Lymphoma. N Engl J Med 1993; 329: 987-94.

4. Coiffier B, Lepage E, Briere J, Herbrecht R, Tilly H, Bouabdallah R, et al. CHOP Chemotherapy plus Rituximab CO compared with CHOP alone in elderly patients with Diffuse Large-B-cell Lymphoma. N Engl J Med 2002; 346 (4): 235-42.

5. Pfreundschuh M, Trümper L, Österborg A, Pettengell R, Trneny M, Imrie K, et al. CHOP-like chemotherapy plus rituximab versus $\mathrm{CHOP}$-like chemotherapy alone in young patients with good-prognosis diffuse large-B-cell lymphoma: a randomised controlled trial by the MabThera International Trial (MInT) Group. Lancet Oncol 2006; 7 (5): 379-91.

6. Pfreundschuh M, Schubert J, Ziepert M, Schmits R, Mohren M, Lengfelder E, et al. Six versus eight cycles of bi-weekly CHOP-14 with or without rituximab in elderly patients with aggressive CD20+ B-cell lymphomas: a randomised controlled trial (RICOVER-60). Lancet Oncol 2008; 9 (2): 105-16.

7. Sehn LH, Berry B, Chhanabhai M, Fitzgerald C, Gill K, Hoskins $\mathrm{P}$, et al. The revised International Prognostic Index (R-IPI) is a better predictor of outcome than the standard IPI for patients with diffuse large B-cell lymphoma treated with R-CHOP. Blood 2007; 109 (5): 1857-62.

8. Alizadeh A, Elsen M, Davis R, Ma C, Lossos I, Rosenwald A, et al. Distinct types of diffuse large B-cell lymphoma identifed by gene expression profling. Nature 2000; 403: 503-11.

9. Yoon N, Ahn S, Yoo HY, Kim SJ, Kim WS, Ko YH. Cell-of-origin of diffuse large B-cell lymphomas determined by the Lymph2Cx assay: better prognostic indicator than Hans algorithm. Oncotarget 2017; 8 (13): 22014-22.

10. Akyurek N, Uner A, Benekli M, Barista I. Prognostic significance of MYC, BCL2, and BCL6 rearrangements in patients with diffuse large B-cell lymphoma treated with cyclophosphamide, doxorubicin, vincristine, and prednisone plus rituximab. Cancer 2012; 118 (17): 4173-83.

11. Campo E. MYC in DLBCL: Partners matter. Blood 2015; 126 (22): 2439-40.

12. Li L, Li Y, Que X, Gao X, Gao Q, Yu M, et al. Prognostic significances of overexpression MYC and/or BCL2 in R-CHOP-treated diffuse large B-cell lymphoma: A Systematic review and meta-analysis. Sci Rep 2018; 8 (1): 1-9.

13. Dührsen U, Hüttmann A, Jöckel K-H, Müller S. Positron emission tomography guided therapy of aggressive non-Hodgkin lymphomas - the PETAL trial. Leuk Lymphoma 2009; 50 (11): 1757-60.

14. Kurtova AV, Balakrishnan K, Chen R, Ding W, Schnabl $\mathrm{S}$, Quiroga MP, et al. Diverse marrow stromal cells protect CLL cells from spontaneous and drug-induced apoptosis: Development of a reliable and reproducible system to assess stromal cell adhesion-mediated drug resistance. Blood 2009; 114 (20): 4441-50.

15. Mazumdar R, Evans P, Culpin R, Bailey J, Allsup D. The automated monocyte count is independently predictive of overall survival from diagnosis in chronic lymphocytic leukaemia and of survival following first-line chemotherapy. Leuk Res 37 (6): 614-18.

16. Wilcox RA, Wada DA, Ziesmer SC, Elsawa SF, Comfere NI, Dietz AB, et al. Monocytes promote tumor cell survival in T-cell lymphoproliferative disorders and are impaired in their ability to differentiate into mature dendritic cells. Blood 2009; 114 (14): 2936-44.

17. Waugh DJJ, Wilson C. The interleukin- 8 pathway in cancer. Clin Cancer Res 2008; 14 (21): 6735-41.

18. Lenz G, Wright G, Dave SS, Xiao W, Powell J, Zhao H, et al. Stromal gene signatures in Large-B-cell Lymphomas. N Engl J Med 2008; 359 (22): 2313-23.

19. Dave SS, Wright G, Tan B, Rosenwald A, Gascoyne RD Chan WC, et al. Prediction of Survival in Follicular Lymphoma Based on Molecular Features of Tumor-Infiltrating Immune Cells. N Engl J Med 2004; 351 (21): 2159-69.

20. Cheson BD, Fisher RI, Barrington SF, Cavalli F, 
Schwartz LH, Zucca E, et al. Recommendations for initial evaluation, staging, and response assessment of hodgkin and non-hodgkin lymphoma: The Lugano classification. J Clin Oncol 2014; 32 (27): 3059-67.

21. Wilcox R, Ristow K, Habermann TM, Inwards DJ, Micallef IN, Johnston PB, et al. The absolute monocyte and lymphocyte prognostic score predicts survival and identifies high-risk patients in diffuse large-B-cell lymphoma. Leuk Off J Leuk Soc Am Leuk Res Fund, UK 2011; 25 (9): 1502-9.

22. Chen Y, Neelapu S, Feng L, Bi W, Yang TH, Wang M, et al. Prognostic significance of baseline peripheral absolute neutrophil, monocyte and serum $\beta 2$-microglobulin level in patients with diffuse large b-cell lymphoma: a new prognostic model. Br J Haematol 2016; 175 (2): 290-9.

23. Wu C, Wu X, Zhang X, Chai Y, Guo Q, Li L, et al.
Prognostic significance of peripheral monocytic myeloid-derived suppressor cells and monocytes in patients newly diagnosed with diffuse large b-cell lymphoma. Int J Clin Exp Med 2015; 8 (9): 15173-81.

24. Tadmor T, Bari A, Sacchi S, Marcheselli L, Liardo EV, Avivi I, et al. Monocyte count at diagnosis is a prognostic parameter in diffuse large B-cell lymphoma: Results from a large multicenter study involving 1191 patients in the pre- and post-rituximab era. Haematologica 2014; 99 (1): 125-30.

25. Porrata LF, Ristow KM, Habermann TM, Witzig TE, Colgan JP, Inwards DJ, et al. Peripheral blood absolute lymphocyte/monocyte ratio during rituximab, cyclophosphamide, doxorubicin, vincristine and prednisone treatment cycles predicts clinical outcomes in diffuse large B-cell lymphoma. Leuk Lymphoma 2014; 55 (12): 2728-38. 